\title{
Responses of six Brachiaria spp. accessions to root zone flooding
}

\author{
Luana Pabla de Souza Caetano¹, Moacyr Bernardino Dias-Filho²
}

\footnotetext{
${ }^{1}$ Museu Paraense Emilio Goeldi, Av. Perimetral, 1901, CEP: 66077-530, Belém, PA, Brazil.

2 Embrapa Amazônia Oriental, Caixa Postal 48, CEP: 66017-970, Belém, PA, Brazil.
}

\begin{abstract}
Some morphophysiological responses of Brachiaria brizantha cv. Marandu, cv. Piatã, cv. Arapoty, B163, B166 and B. ruziziensis R124 were compared in plants grown in pots, under flooded and well-drained conditions. Flooding reduced leaf elongation rate in all accessions. Leaf dry mass production was lower under flooding than in the control plants in all the studied accessions, except in cv. Piatã. Root dry mass production was reduced by flooding in cv. Marandu and in R124 while the proportion of biomass allocated to roots was reduced by flooding only in R124. It was not possible to detect significant differences between water regimes in the percentage of biomass allocated to culms and leaves for all accessions. Flooding decreased the number of tillers in cv. Marandu, in B163, B166 and in R124. Relative growth rate was decreased by flooding in cv. Marandu, in B163 and in R124. Flooding reduced gas exchange parameters in all accessions, but cv. Arapoty. The accessions tested differ in their relative tolerance to flooding. B. brizantha cv. Arapoty is considered the most tolerant. B. ruziziensis R124 is the most sensitive, followed by B. brizantha cv. Marandu. B. brizantha cv. Piatã, B163 and B166 are intermediate in flooding tolerance.
\end{abstract}

Key Words: biomass allocation, Brachiaria brizantha, leaf elongation rate, photosynthesis, relative growth rate

\section{Resposta de seis acessos de capim-braquiária ao alagamento do solo}

RESUMO - Respostas morfofisiológicas de Brachiaria brizantha, cultivares Marandu, Piatã, Arapoty, B163, B166 e B. ruziziensis (R124), foram comparadas em plantas cultivadas em vasos, sob alagamento ou em solo bem drenado. O alagamento do solo reduziu a taxa de alongamento foliar de todos os acessos. Sob alagamento, houve queda na produção de biomassa de folhas em todos os acessos, com exceção do cultivar Piatã. A produção de raízes reduziu com o alagamento do solo no cv. Marandu e em R124, enquanto o percentual de biomassa alocado para as raízes diminuiu apenas no acesso R124. Não foi possível detectar diferenças entre regimes de água na alocação de biomassa para colmos e folhas em nenhum dos acessos. O alagamento diminuiu o número de perfilhos nos cultivares Marandu, B163, B166 e R124. Com o alagamento do solo, a taxa de crescimento relativo diminuiu nos cultivares Marandu, B163 e R124. Com exceção do cultivar Arapoty, o alagamento reduziu as trocas gasosas de todos os acessos estudados. Os acessos avaliados diferiram quanto à tolerância relacionada ao alagamento do solo: o cv. Arapoty é relativamente mais tolerante, enquanto o B. ruziziensis (R124) é menos tolerante, seguido pelo Marandu, e os cultivares Piatã, B163 e B166 têm tolerância intermediária.

Palavras-chave: alocação de biomassa, alongamento foliar, Brachiaria brizantha, fotossíntese, taxa de crescimento relativo

\section{Introduction}

In tropical pastures periods of excess soil water can be relatively common events. Usually, excess water in pasture soils (waterlogging or flooding) is a short-term event and can be caused by the combination of intensive rains and low soil drainage (e.g., soils with a drainage impediment layer). In addition, management practices that lead to soil compactation (e.g., overgrazing) can disrupt the natural drainage ability of these soils, making them more prone to intermittent flooding or waterlogging periods.
Among the problems related to temporary excess soil water in pastures of tropical America, marandugrass (Brachiaria brizantha cv. Marandu) death syndrome is of particular importance (Dias-Filho, 2006). This problem was initially reported in Central America (Zúñiga et al., 1998) and for the last few years has become a major cause of pasture degradation in the North of Brazil, particularly in the states of Acre, Amazonas, Pará, Rondônia, Mato Grosso, Tocantins and Maranhão, where over $40 \%$ of the total pasture areas and $35 \%$ of the Brazilian beef cattle heard are present (DiasFilho \& Andrade, 2005). This syndrome is thought to be 
caused by the very low tolerance of marandugrass to excess soil water which adversely affects plant metabolism, resulting in predisposition to biotic stresses like fungal infection (Dias-Filho, 2005, 2006). Similar response mechanisms have also been reported in the literature for other plant species subjected to soil flooding, such as Eucalyptus marginata (Burgess et al., 1998, 1999), tomato (Chérif et al., 1997), and oak (Robin et al., 2001).

So far, the only economically viable alternative to cope with the death syndrome in areas prone to this problem is the replacement of marandugrass by grass species or cultivars with greater tolerance to temporary flooding or waterlogging (Andrade \& Valentim, 2006; Dias-Filho, 2005, Dias-Filho \& Andrade, 2005). Thus, information on the relative tolerance of forage grasses to excess soil water is essential to deal with this problem. For that reason, research programs to release new forage grass cultivars, such as the one currently being conducted for Brachiaria by the Brazilian Agricultural Research Corporation (Embrapa) (Valle et al., 2001), should prioritize the screening for flood tolerance in the evaluation process of these accessions.

Although knowledge about the tolerance of tropical forage grasses to excess soil water is key in determining the potential of use of these plants in habitats subjected to this stress, studies investigating this tolerance and the mechanisms involved in the responses of these plants to water stress have received little attention throughout the tropics (e.g., Baruch, 1994a; 1994b; Kibbler \& Bahnisch, 1999; Medina \& Motta, 1990; Ram, 2000), and particularly in Brazil (e.g., Dias-Filho, 2002; Dias-Filho \& Carvalho, 2000; Haddade et al., 2002; Mattos et al., 2005).

We hypothesized that Brachiaria spp. accessions show differential ability to tolerate soil flooding. The objective of the present study was, therefore, to evaluate and compare selected physiological and morphological responses of five accessions of Brachiaria brizantha (including marandugrass) and one of $B$. ruziziensis under excess soil water.

\section{Material and Methods}

Seeds of Brachiaria brizantha cv. Marandu, cv. Piatã, cv. Arapoty, B163 and B166 and B. ruziziensis (R124), produced from germplasm originally introduced from east Africa in 1984 and 1985 (Valle, 1990) and supplied by Embrapa Beef Cattle, in Campo Grande, MS, Brazil, were germinated in sand and then planted individually in pots with $2 \mathrm{~kg}$ (dry mass) of soil $(3: 2$; organic soil to cured manure). Seventeen days after planting, pots were fertilized with a solution of $40 \mathrm{mg}$ of $\mathrm{P}\left(\mathrm{Ca}\left(\mathrm{H}_{2} \mathrm{PO}_{5}\right)_{2} \cdot \mathrm{H}_{2} \mathrm{O}\right) \mathrm{kg}^{-1}$ soil $)$.
One day after this fertilization, $50 \mathrm{mg} \mathrm{N}$ (urea) $\mathrm{kg}^{-1}$ soil was applied. Plants were grown outdoors for the duration of the experiment under a shade net that intercepted ca. $60 \%$ of direct solar radiation. The trial was conducted at the Embrapa Eastern Amazonia headquarters, in Belém ( $\left.1^{\circ} 28^{\prime} \mathrm{S}\right), \mathrm{PA}$, Brazil. Each pot was watered daily and fertilized every other day with $10 \mathrm{~mL}$ of a water soluble fertilizer solution (15:30:15; $\left.\mathrm{N}: \mathrm{P}_{2} \mathrm{O}_{5}: \mathrm{K}_{2} \mathrm{O} ; 10 \mathrm{~g} \mathrm{~L}^{-1}\right)$. Flooding was imposed 20 days after planting by inundating the pots up to $3 \mathrm{~cm}$ above the soil level. Control pots were free-draining and watered daily. Flooding lasted five days for all accessions. Previous studies (Dias-Filho, 2002; M.B. Dias-Filho, unpublished data) have indicated that this period was ideal for detecting differences among forage grasses genotypes in their relative ability to tolerate flooding. All plants remained vegetative during the experimental period.

The length of a young expanding leaf blade (with the ligule not yet exposed) in a vegetative tiller of each plant was measured with a ruler at around the same time every day, starting immediately after flooding was imposed. Leaves being measured were marked with a plastic ring. Once the ligule was exposed, a new leaf, on the same plant, was marked and measured. Daily leaf elongation was calculated as the difference between leaf lengths of two consecutive days.

All plants were harvested at the end of the experiment; the number of tillers was counted for each plant and plant material was divided into leaf blades, culms (sheath and stem) and roots. Roots were washed free of soil using a manually manipulated jet spray of water. Plant dry mass was obtained by drying the plant material at $65^{\circ} \mathrm{C}$ for $48 \mathrm{~h}$. Leaf, culm and root mass ratios (respectively, leaf, culm and root dry mass per unit of dry mass of whole plant, LMR, CMR and RMR) were calculated according to Hunt (1990). Relative growth rate (change in total dry mass per total dry mass of plant per day, RGR) was also calculated.

Net photosynthesis, stomatal conductance and transpiration were measured with an open flow infrared gas analyzer with an attached red LED light source (LI-6400, Li-Cor, Inc., Lincoln, NE, EUA). Measurements were made between 9:00 a.m. and 11:00 a.m., local time, on the second and fourth days of flooding, on one young, fully expanded leaf blade of a vegetative tiller on each plant under a constant light level of $1,000 \mu \mathrm{mol} \mathrm{m} \mathrm{m}^{-2} \mathrm{~s}^{-1}$. Gas exchange parameters were calculated on a leaf area basis. Data were pooled for analysis and presentation due to similarities in the responses between the two evaluation dates.

Pots were arranged in a factorial arrangement within a completely randomized design with four replicates. Differences in dry mass production and allocation, net 
photosynthesis, stomatal conductance, transpiration and relative growth rate were assessed by two-way analyses of variance (ANOVA) with treatments (control and flooding) and accessions as main effects. Differences in leaf elongation rate throughout the experimental period were assessed by three-way ANOVA with treatments, accessions and evaluation dates as main effects. The assumption of homogeneity of variances and normality were tested for each ANOVA and, when necessary, data were log transformed. Transformed values were back transformed for presentation. Post hoc contrasts were calculated for assessing differences between treatments within the same accession whenever appropriate.

Factor analysis was used with the objective of grouping together (i.e., to classify) those accessions having the greatest similarities in their relative tolerance to flooding. Data for factor analysis were the mean difference between control and flooded plants in leaf elongation rate, leaf and root dry mass production, total dry mass production, relative growth rate, number of tillers, net photosynthesis, stomatal conductance and transpiration. The rationale being: the lower the difference between control and flooded plants, the higher the relative tolerance to flooding of that particular accession. All data were standardized to a mean of 0 and a standard deviation of 1 before conducting the analysis. The results of this analysis were presented as a two-dimensional plot of unrotated factor loadings.

The statistical package STATISTICA for Windows release 6.1 (StatSoft, Inc., Tulsa, USA) was used for all computations of the data.

\section{Results and Discussion}

Soil flooding reduced mean leaf elongation rate of all the studied accessions $\left(\mathrm{F}_{5,211}=3.92 ; \mathrm{P}=0.002\right)$. The mean reduction in leaf elongation rate throughout the evaluation period was $48.6 \%$ for marandugrass, $56.3 \%$ for cv. Piatã, $35.6 \%$ for cv. Arapoty, $28.3 \%$ for B163, $48.5 \%$ for B166 and $40.9 \%$ for R124 (Figure 1). Similar results were reported by Dias-Filho (2002) and Mattos et al. (2005) studying the morphological responses of Brachiaria species under soil flooding.

According to Dias-Filho \& Carvalho (2000), in Brachiaria spp. leaf elongation rate is related to the tolerance to flooding and could be used as an early detection mechanism of relative flood tolerance in Brachiaria spp. In the present study all accessions showed an immediate (day one) decrease in leaf elongation rate due to flooding,
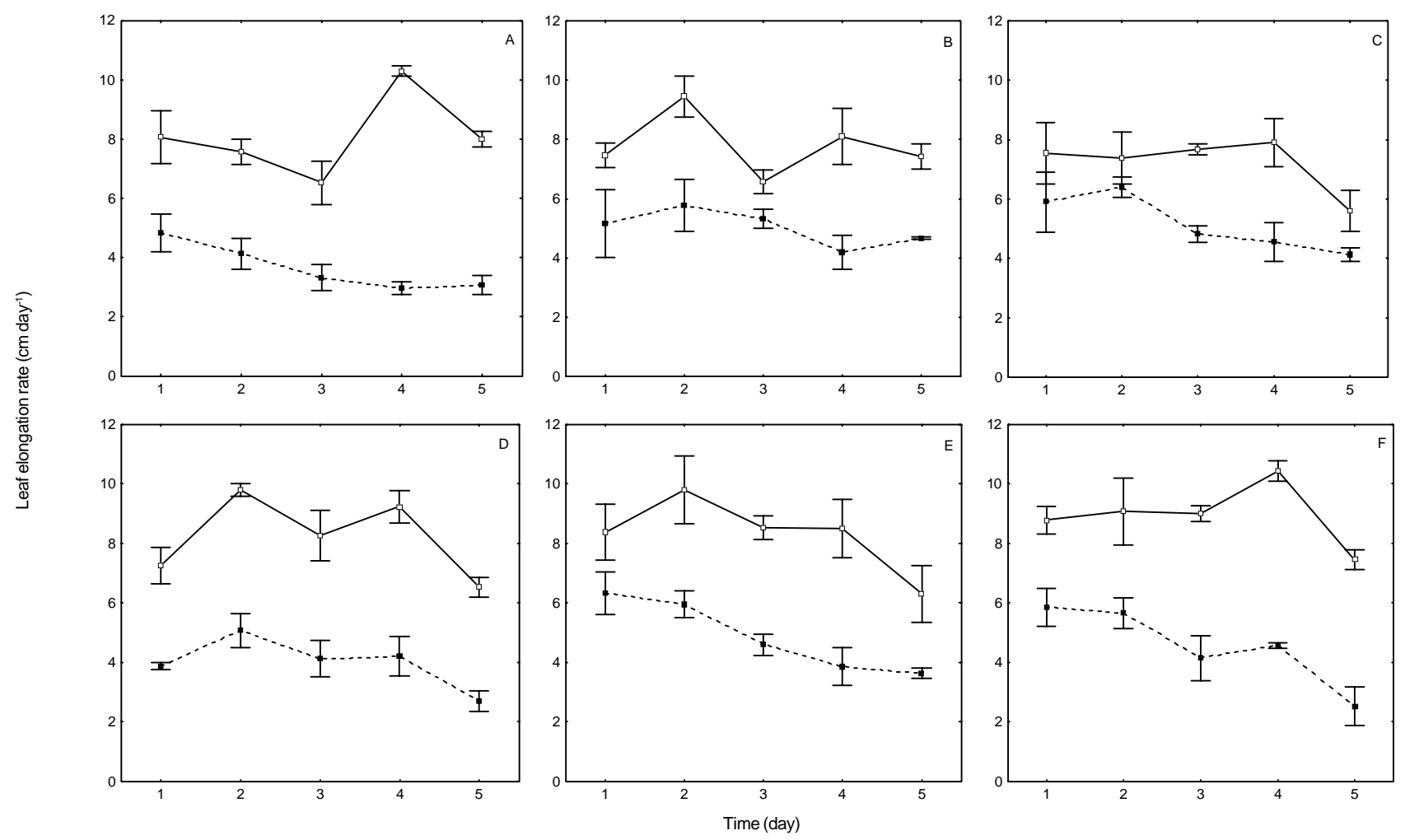

Figure 1 - Leaf elongation rate of Brachiaria brizantha cultivar Piatã (A), Arapoty (B), B163 (C), B166 (D), cultivar Marandu (E) and B. ruziziensis R124 (F), under well-drained (open symbols, solid lines) and flooding (closed symbols, dotted lines) soil. Values are means \pm S.E. 
indicating a low overall tolerance of these accessions to this stress. However, the reduction magnitude varied almost two-fold among all accessions, suggesting distinct degrees of relative flood tolerance.

A significant accession $x$ treatment interaction was detected for relative growth rate $(\mathrm{RGR})\left(\mathrm{F}_{5,25}=6.76 ; \mathrm{P}<0.001\right)$ (Figure 2). Post hoc contrasts of differences between treatments, within the same accession, showed that R124 $\left(\mathrm{F}_{1,25}=59.1 ; \mathrm{P}<0.0001\right)$, marandugrass $\left(\mathrm{F}_{1,25}=7.16 ; \mathrm{P}=0.013\right)$ and $\mathrm{B} 163\left(\mathrm{~F}_{1,25}=9.73 ; \mathrm{P}=0.0045\right)$ suffered significant reductions in RGR (respectively $70.2 \%, 66.1 \%$ and $54.7 \%$ ) due to flooding. No differences between treatments could be detected for cv Piatã, Arapoty and B166. However, a clear tendency for lower RGR values were always observed in flooded plants.

Flooding reduced leaf biomass production for most of the accessions tested $\left(\mathrm{F}_{5,25}=3.39 ; \mathrm{P}=0.018\right)$ (Figure 3$)$. Only in cultivar Piatã it was not possible to detect statistical differences between treatments for leaf biomass production $\left(\mathrm{F}_{1,25}=0.76 ; \mathrm{P}=0.39\right)$. Mean reduction in leaf production due to soil flooding was maximal in R124 (64.2\%) and in marandugrass $(62 \%)$.

Root dry mass was significantly reduced by flooding in $\mathrm{R} 124(82 \%)\left(\mathrm{F}_{1,25}=31.07 ; \mathrm{P}<0.001\right)$ and in marandugrass $(74 \%)\left(\mathrm{F}_{1,25}=7.59 ; \mathrm{P}<0.01\right)$. For all the other accessions, although there was a tendency for lower root dry mass values under flooding, no statistical differences could be detected between flooded and control plants (Figure 4).

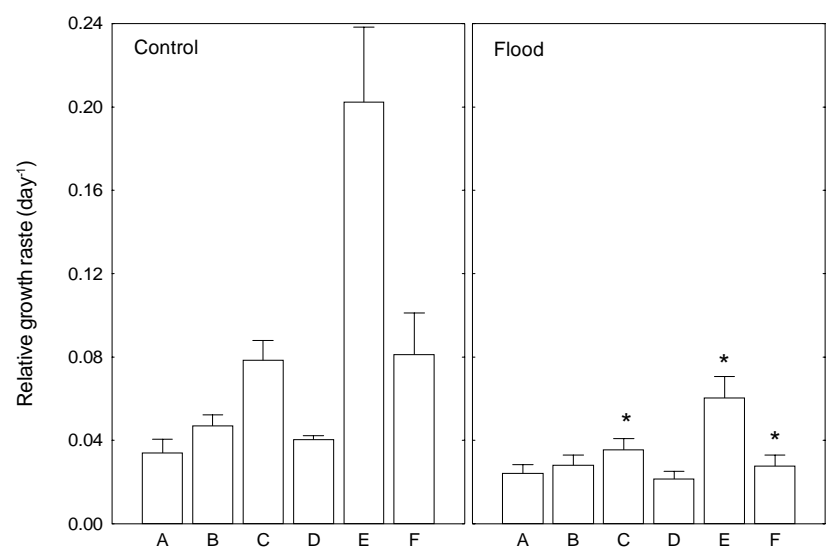

Figure 2 - Relative growth rate of Brachiaria brizantha cultivar Piatã (A), Arapoty (B), B163 (C), B166 (D), cultivar Marandu $(E)$ and $B$. ruziziensis R124 $(F)$, under well-drained (Control) and flooding (Flood). Values are means \pm S.E. An asterisk indicates statistical difference (post hoc contrast; $\mathrm{P}<0.05$ ) between treatments for a particular accession.
Flooding reduced the mean number of tillers in B166 $(100 \%)\left(\mathrm{F}_{1,25}=16.4 ; \mathrm{P}<0.001\right), \mathrm{R} 124(74.2 \%)\left(\mathrm{F}_{1,25}=177.5\right.$; $\mathrm{P}<0.0001)$, marandugrass $(55.5 \%)\left(\mathrm{F}_{1,25}=8.39 ; \mathrm{P}<0.008\right)$ and $\mathrm{B} 163(54.9 \%)\left(\mathrm{F}_{1,25}=11.6 ; \mathrm{P}<0.001\right)$. However, in cv. Arapoty and cv. Piatã it was not possible to detect significant differences between treatments in the mean number of tillers (data not shown). For most accessions tillering behavior of flooded plants was highly correlated to RGR and leaf biomass production (data not shown); the exception was B166 in which the decline in tillering did not affect those parameters.

For most of the accessions biomass allocation patterns were not significantly affected by flooding (Table 1). For R124, however, the amount of biomass allocated to roots (RMR) was significantly lower $\left(\mathrm{F}_{1,25}=7.47 ; \mathrm{P}=0.01\right)$ in flooded plants. For the others accessions RMR generally showed a stronger tendency to be lower under flooding. An opposite tendency was observed for biomass allocated to leaves (LMR), while no clear pattern could be observed for biomass allocated to culms (CMR).

Miller \& Zedler (2003) reported that the grasses Phalaris arundinacea and Spartina pectinata allocated more biomass to aboveground with flooding. Similarly, Rubio \& Lavado (1999) observed a sharp decrease in the root:shoot ratio in the grasses Paspalum dilatatum and Danthonia montevidensis under flooding. Dias-Filho \& Carvalho (2000) and Dias-Filho (2002) also found a decrease in RMR and an increase in LMR in flooded

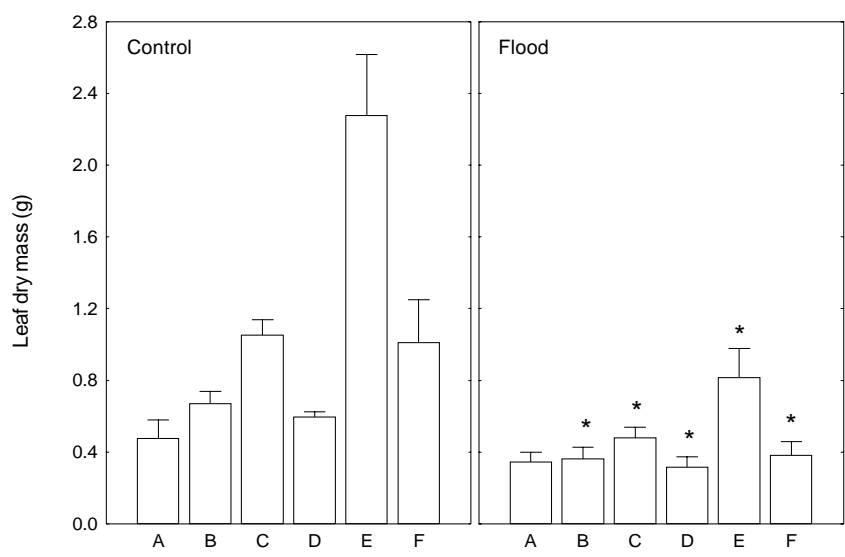

Figure 3 - Leaf dry mass production of Brachiaria brizantha cultivar Piatã (A), Arapoty (B), B163 (C), B166 (D), cultivar Marandu (E) and B. ruziziensis R124 (F), under well-drained (Control) and flooding (Flood). Values are means $\pm S$.E. An asterisk indicates statistical difference (post hoc contrast; $\mathrm{P}<0.05$ ) between treatments for a particular accession. 


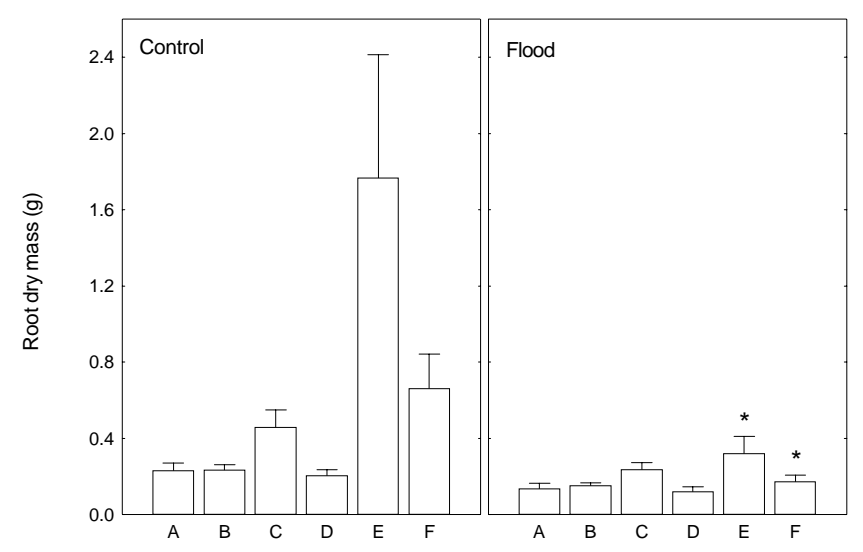

Figure 4 - Root dry mass production of Brachiaria brizantha cultivar Piatã (A), Arapoty (B), B163 (C), B166 (D), cultivar Marandu (E) and B. ruziziensis R124 (F), under well-drained (Control) and flooding (Flood). Values are means $\pm S$. E. An asterisk indicates statistical difference (post hoc contrast; $\mathrm{P}<0.05$ ) between treatments for a particular accession.

Table 1 - Leaf mass ratio (LMR, $\mathrm{kg} \mathrm{kg}^{-1}$ ), culm mass ratio (CMR, $\mathrm{kg} \mathrm{kg}^{-1}$ ) and root mass ratio (RMR, $\mathrm{kg} \mathrm{kg}^{-1}$ ) of Brachiaria spp. accessions under flooding and control treatments at the last evaluation date. Values are means ( \pm s.e.), $\mathrm{n}=4$. For each accession significance between means within columns is given by ${ }^{*}=\mathrm{P}<0.05$ (post hoc contrasts)

\begin{tabular}{llll}
\hline Treatment & LMR & CMR & RMR \\
\hline
\end{tabular}

B. brizantha cv. Piatã

$\begin{array}{llllll}\text { Control } & 0.46(0.03) & 0.29(0.02) & 0.25(0.03) \\ \text { Flooding } & 0.52(0.03) & 0.28(0.02) & 0.20(0.03)\end{array}$

B. brizantha cv. Arapoty

$\begin{array}{llllll}\text { Control } & 0.51(0.03) & 0.31(0.02) & 0.18(0.03) \\ \text { Flooding } & 0.46(0.02) & 0.34(0.02) & 0.20(0.02)\end{array}$

$\begin{array}{lllllll}\text { Flooding } & 0.46(0.02) & 0.34(0.02) & 0.20(0.02)\end{array}$

B. brizantha B163

Control $\quad 0.48(0.03) \quad 0.31(0.02) \quad 0.20(0.03)$

Flooding $\quad 0.49(0.02) \quad 0.27(0.02) \quad 0.23(0.02)$

B. brizantha B166

$\begin{array}{llllll}\text { Control } & 0.53(0.03) & 0.29 & (0.02) & 0.18(0.03)\end{array}$

Flooding $\quad 0.53(0.03) \quad 0.27(0.02) \quad 0.20(0.03)$

B. brizantha cv. Marandu

Control $\quad 0.45(0.03) \quad 0.26(0.02) \quad 0.28(0.03)$

Flooding $\quad 0.50(0.03) \quad 0.28(0.02) \quad 0.22(0.03)$

B. ruziziensis $\mathrm{R} 124$

Control $\quad 0.42(0.03) \quad 0.29(0.02) \quad 0.29 *(0.03)$

$\begin{array}{lllll}\text { Flooding } & 0.48(0.03) & 0.34(0.02) & 0.18(0.03)\end{array}$
Brachiaria spp. Also, a higher proportion of biomass allocated to leaves was observed in flooded Leontodon taraxacoides (Asteraceae) by Grimoldi et al. (1999). In contrast, Mattos et al. (2005) reported that flooding caused a lower LMR in Brachiaria spp.

As suggested by Rubio \& Lavado (1999), the reduced allocation to roots in flooded plants could be a strategy to decrease the higher maintenance respiration of roots, when compared to that of shoots. Also, because roots cannot satisfy their own oxygen requirements, a smaller root system could be more easily ventilated by the shoot under waterlogging conditions.

There was a significant accession $\mathrm{x}$ treatment interaction on net photosynthesis $\left(\mathrm{F}_{5,274}=18.92 ; \mathrm{P}<0.0001\right)$, stomatal conductance $\left(\mathrm{F}_{5,274}=29.97 ; \mathrm{P}<0.0001\right)$ and transpiration $\left(\mathrm{F}_{5,274}=12.67 ; \mathrm{P}<0.0001\right)$. Post hoc contrasts of differences between treatments, within the same accession, revealed that only in cultivar Arapoty net photosynthesis was not significantly reduced by flooding (Figure 5). This reduction, however, was highest for R124 (63\%), followed by marandugrass (43\%) and by cv. Piatã (39\%). A similar trend was observed for stomatal conductance (Figure 5) and transpiration (Figure 5). As with net photosynthesis, R124, marandugrass and cv. Piatã experienced the highest percentage decline due to flooding in leaf conductance $(67$, 51 and $44 \%$, respectively) and transpiration (56,34 and $32 \%$, respectively), while no effect could be detected in $\mathrm{cv}$. Arapoty. Previous studies have also shown a sharp decline of net photosynthesis and stomatal conductance of marandugrass subjected to root zone flooding (Dias-Filho, 2002; Dias-Filho \& Carvalho, 2000). Interestingly, Mattos et al. (2005) found that net photosynthesis and stomatal conductance were not affected by flooding in marandugrass. The explanation could be the relatively low photosynthetic performance ( $\left.9 \mu \mathrm{mol} \mathrm{m} \mathrm{m}^{-2} \mathrm{~s}^{-1}\right)$ of control (field capacity) plants observed in that study, which could be viewed as an indication that those plants probably lacked the proper conditions (environmental or physiological) to express their full photosynthetic potential.

There was a significant and positive linear relationship between net photosynthesis and stomatal conductance for flooded plants from all accessions except for cultivar Arapoty, which showed a negative relationship between those parameters $\left(\mathrm{r}^{2}=0.86 ; \mathrm{P}<0.001\right)$. The positive relationship was strongest for cultivar Piatã $\left(r^{2}=0.99\right.$; $\mathrm{P}<0.001)$, but weaker for cultivar Marandu $\left(\mathrm{r}^{2}=0.65 ; \mathrm{P}<0.001\right)$. The strong positive relationship between net photosynthesis and stomatal conductance suggests that stomatal inhibition was a major factor affecting $\mathrm{CO}_{2}$ assimilation. However, the 

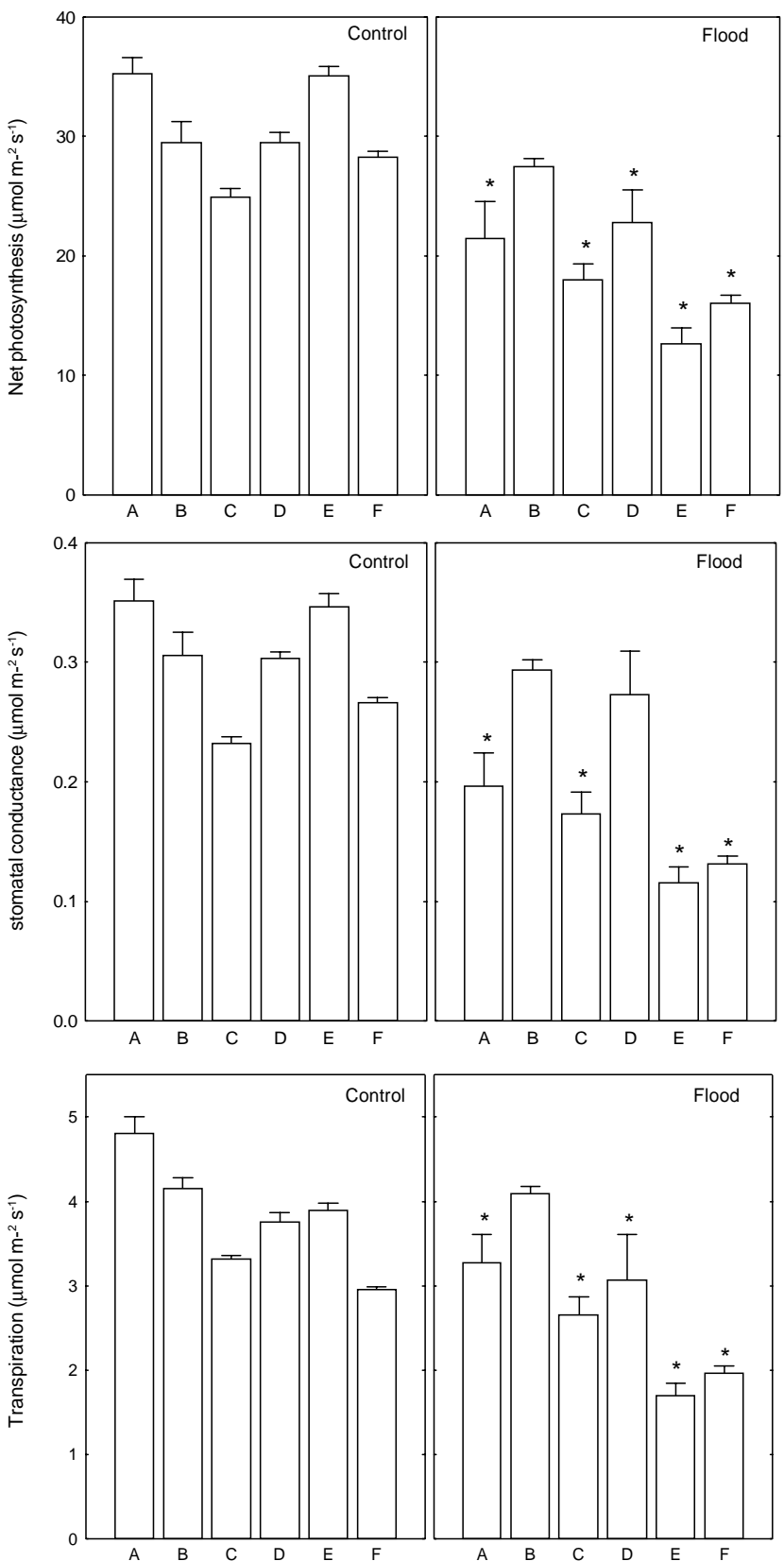

Figure 5 - Net photosynthesis, stomatal conductance and transpiration of Brachiaria brizantha cultivar Piatã (A), Arapoty (B), B163 (C), B166 (D), cultivar Marandu $(\mathrm{E})$ and $B$. ruziziensis R124 (F), under well-drained (Control) and flooding (Flood). Values are means \pm S.E. An asterisk indicates statistical difference (post hoc contrast; $\mathrm{P}<0.05$ ) between treatments for a particular accession.

reduction in net photosynthesis observed in flooded plants was not always accompanied by a reduction in the internal $\mathrm{CO}_{2}$ concentration (data not shown), which indicates that, in the present study, stomatal aperture, although important, was not the only limiting factor for the decrease in the photosynthetic capacity of flooded plants (Liao \& Lin, 2001).

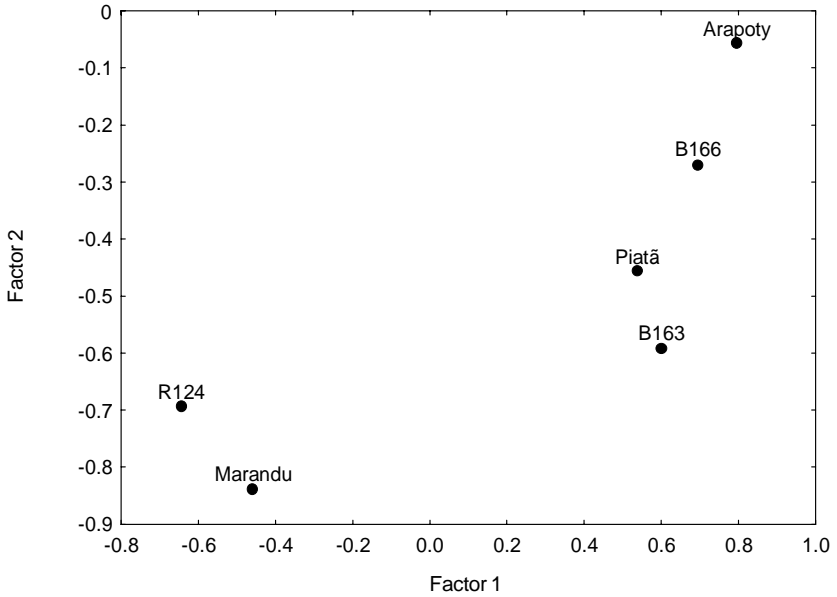

Figure 6 - Factor analysis plot of Brachiaria spp. accessions under flooding.

The plot generated from the factor analysis (Figure 6) confirmed our hypothesis that the six Brachiaria spp. accessions show a contrasting ability to tolerate root zone flooding.

\section{Conclusions}

B. brizantha cv. Arapoty is the accession relatively most tolerant to flooding. B. brizantha cv. Piatã, B163 and B166 are intermediate in flooding tolerance. B. ruziziensis (R124), followed by marandugrass, are the most floodsensitive accessions.

\section{Acknowledgements}

To Cacilda Borges do Valle for supplying the germplasm evaluated in this trial and for useful comments on earlier versions of this paper. This work was partially supported by the Fundação de Apoio à Pesquisa Agropecuária e Ambiental - Fundapam and by the Associação para o Fomento à Pesquisa de Melhoramento de Forrageiras Tropicais - Unipasto.

\section{Literature Cited}

ANDRADE, C.M.S.; VALENTIM, J.F. Soluções tecnológicas para a síndrome da morte do capim-marandu. In: BARBOSA, R.A. (Ed.) Morte de pastos de braquiárias. Campo Grande: Embrapa Gado de Corte, 2006. p.175-197.

BARUCH, Z. Responses to drought and flooding in tropical forages grasses. I. Biomass allocation, leaf growth and mineral nutrients. Plant and Soil, v.164, p.87-96, 1994a.

BARUCH, Z. Responses to drought and flooding in tropical forages grasses. II. Leaf water potential, photosynthesis rate and alcohol dehydrogenase activity. Plant and Soil, v.164, p.87-96, 1994b.

BURGESS, T.; McCOMB, J.; HARDY, G.E.St.J. et al. Influence of low oxygen levels in aeroponics chambers on eucalypt roots infected 
with Phytophthora cinnamomi. Plant Disease, v.82, p.368-373, 1998.

BURGESS, T.; McCOMB, J.A.; COLQUHOUN, I. et al. Increased susceptibility of Eucalyptus marginata to stem infection by Phytophthora cinnamomi resulting from root hypoxia. Plant Pathology, v.48, p.797-806, 1999.

CHÉRIF, M.; TIRILLY, Y.; BÉLANGER, R.R. Effect of oxygen concentration on plant growth, lipidperoxidation, and receptivity of tomato roots to Pythium $\mathrm{F}$ under hydroponic conditions. European Journal of Plant Pathology, v.103, p.255-264, 1997.

DIAS-FILHO, M.B. Tolerance to flooding in five Brachiaria brizantha accessions. Pesquisa Agropecuária Brasileira, v.37, p.439-447, 2002.

DIAS-FILHO, M.B. Opções forrageiras para áreas sujeitas a inundação ou alagamento temporário. In: SIMPÓSIO SOBRE MANEJO DE PASTAGEM, 22., 2005, Piracicaba. Palestras... Piracicaba: Fundação de Estudos Agrários Luiz de Queiroz, 2005. p.71-93.

DIAS-FILHO, M.B. Respostas morfofisiológicas de Brachiaria spp. ao alagamento do solo e a síndrome da morte do capim-marandu. In: BARBOSA, R.A. (Ed.) Morte de pastos de braquiárias. Campo Grande: Embrapa Gado de Corte, 2006. p.83-101.

DIAS-FILHO, M.B.; CARVALHO, C.J. Physiological and morphological responses of Brachiaria spp. to flooding. Pesquisa Agropecuária Brasileira, v.35, p.1959-1966, 2000

DIAS-FILHO, M.B.; ANDRADE, C.M.S. Pastagens no ecossistema do trópico úmido. In: SIMPÓSIO SOBRE PASTAGENS NOS ECOSSISTEMAS BRASILEIROS, 2., 2005, Goiânia. Anais... Goiânia: Sociedade Brasileira de Zootecnia, 2005. p. 95-104.

GRIMOLDI, A.A.; INSAUSTI, P.; ROITMAN, G.G. et al. Responses to flooding intensity in Leontodon taraxacoides. New Phytologist, v.141, p.119-128, 1999.

HADADDE, I.R.; OBEID, J.A.; FONSECA, D.M. et al. Crescimento de espécies forrageiras tropicais submetidas a diferentes períodos de alagamento. Revista Brasileira de Zootecnia, v.31, p.1924-1930, 2002.

JACKSON, M.B. Long-distance signaling from roots to shoots assessed: the flooding story. Journal of Experimental Botany, v. 53, p.175-181, 2002.
KIBBLER, H.; BAHNISCH, L.M. Physiological adaptations of Hymenachne amplexicaulis to flooding. Australian Journal of Agricultural Research, v.39, p.429-435, 1999.

LIAO, C.T.; LIN, C.H. Physiological adaptation of crop plants to flooding stress. Proceedings of the National Science Council, v.25, p.148-157, 2001.

MATTOS, J.L.S.; GOMIDE, J.A.; MARTINEZ Y HUAMAN, C.A. Crescimento de espécies do gênero Brachiaria sob alagamento em casa de vegetação. Revista Brasileira de Zootecnia, v.34, p.765-773, 2005.

MEDINA, E.; MOTTA, N. Metabolism and distribution of grasses in tropical flooded savannas in Venezuela. Journal of Tropical Ecology, v.6, p.77-89, 1990.

MILLER, R.C.; ZEDLER, J.B. Responses of native and invasive wetland plants to hydroperiod and water depth. Plant Ecology, v. 167, p.57-69, 2003.

RAFTOYANNIS, Y.; RADOGLOU, K. Physiological responses of beech and sessile oak in a natural mixed stand during a dry summer. Annals of Botany, v.89, p.723-730, 2002.

RAM, S. Role of alcohol dehydrogenase, malate dehydrogenase and malic enzyme in flooding tolerance in Brachiaria species. Journal of Plant Biochemistry and Biotechnology, v.9, p. $45-47,2000$.

ROBIN, C.; CAPRON, G.; DESPREZ-LOUSTAU, M.L. Root infection by Phytophthora cinnamomi in seedlings of three oak species. Plant Pathology, v.50, p.708-716, 2001.

RUBIO, G.; LAVADO, R.S. Acquisition and allocation of resources in two waterlogging-tolerant grasses. New Phytologist, v.143, p.539-546, 1999.

VALLE, C.B. Coleção de germoplasma de espécies de Brachiaria no CIAT. Estudos básicos visando ao melhoramento genético. Campo Grande: Embrapa-CNPGC, 1990. 33p. (Documentos, 46).

VALLE, C.B.; EUCLIDES, V.P.B.; MACEDO, M.C.M. et al. Selecting new Brachiaria for Brazilian pastures. In: INTERNATIONAL GRASSLAND CONGRESS, 19., 2001, São Pedro. Proceedings... Piracicaba: Fundação de Estudos Agrários Luiz de Queiroz, 2001. (CD-ROM).

ZÚÑIGA P.C.; GONZÁLEZ Q.R.; BUSTAMANTE, E. et al. Influencia de la humedad del suelo sobre la susceptibilidad de Brachiaria a hongos patógenos. Manejo Integrado de Plagas, v.49, p.51-57, 1998. 